\title{
Improving the Attention Performance in High- Functioning Autistics during Memorization Lesson through Neurofeedback Training Approaches
}

\author{
Nur Madihah Jafar \\ University of Malaya, madihahjafar89@siswa.um.edu.my \\ Nazean Jomhari \\ University of Malaya, nazean@um.edu.my \\ Mohd Yakub@Zulkifli Mohd Yusoff \\ University of Malaya, zulkifliy@um.edu.my \\ DOI: https://doi.org/10.22452/usuluddin.vol47no2.6
}

\begin{abstract}
Most students with high-functioning autism have difficulties in paying attention that may affect in memorizing lesson material which will impede their learning progress. Several researches have shown that neurofeedback training (NFT) is successful in training the autistics' attention performance. Thus, the purpose of this study is to measure and compare the effectiveness of two versions of an invention using different NFT approaches on the attention performance of high-functioning autistic (HFA) during memorization of the lesson material. The results from this study showed that the ratio of students those categorized in high attention increased from 3:10 to 4:5 when using the version 2 learning tool which resulted in more effective in improving the HFAs' attention performance. The findings of this study suggested that the invention of memorization tool was effective for the purpose of enhancing the HFAs' attention performance during memorization lesson with the adaptation of NFT approaches; visual feedback, audio feedback, verbal response, and reward system.
\end{abstract}

Keywords: neurofeedback training, biofeedback, attention, memorization, visual feedback, high-functioning autism

\section{Introduction}

The HFA have been reported facing attentional deficits which are caused by the inability to properly handle the attention field where the visual spatial attention is located. Another reason of short attention duration especially for most lessons learnt is caused by the chosen of teaching tools as teaching aids. In order to assist them with these deficits, teachers should be more creative and 
innovative $^{1}$ in matching the teachings in school with students' interest so that the knowledge transfer process will not be taken as dull and uninteresting by the students ${ }^{2}$. Other than using conventional style in teaching the students, lots of technology gadgets can be used in capturing students' attention during lessons learnt ${ }^{3}$. Designing technology applications specifically for the HFAs is rather a new invention that is increasingly gaining attention ${ }^{4}$.

Previous researches showed that NFT proved its effectiveness in treating autism ${ }^{5}[6],{ }^{6}[7]$. It is also had proven assisting people with autism in evaluating their condition as well as improving the symptoms of attentional deficits such as auditory and visual attention ${ }^{78910}$. Moreover, in the education aspect, those people suffer from attentional deficits are also given training using neurofeedback to increase attention span in order to improve their

1 Maimun Aqsha Lubis et al. "The Effectiveness of Strategies and Techniques in Teaching and Learning Islamic Education", WSEAS Transactions on Information Science and Applications 6, No. 8 (2009), pp. 218-224.

2 Wan Noor Hazlina Wan Jusoh and Kamaruzaman Jusoff, "Using Multimedia In Teaching Islamic Studies," Journal Media and Communication Studies 1, No. 5 (2009), pp. 86-94.

3 Siti Iradah Ismail and Rabiah Abdul Kadir, "EduTism: An Assistive Educational System for the Treatment of Autism Children." In Visual Informatics: Sustaining Research and Innovations, eds. Halimah Badioze Zaman et al. (Selangor: Springer Berlin Heidelberg; 2011), pp. 193-204.

4 K. Porayska-Pomsta et al. "Developing Technology for Autism: An Interdisciplinary Approach," Personal and Ubiquitous Computing 16, No. 2 (2012), pp. 117-127.

5 D. Corydon Hammond, "What Is Neurofeedback?" Journal of Neurotheraphy 10, No. 4 (2007), pp. 25-36.

6 Wonjae Choi, Seungwon Lee and Junhyuck Park, "EEG-Biofeedback Intervention Improves Balance in Stroke Survivor," Indian Journal of Science \& Technology 8, No. 18 (2015), pp. 1.

7 D. Corydon Hammond, "What Is Neurofeedback?," pp. 25-36.

8 D. Corydon Hammond, "What Is Neurofeedback?: An Update," Journal of Neurotheraphy 15, No. 4 (2011), pp. 305-336.

9 Joel F. Lubar, "Neurofeedback for the Management of AttentionDeficit/Hyperactivity Disorders." In Biofeedback: A Practitioner's Guide, eds. Mark S Schwartz (2nd ed, New York: Guilford Press; 1995), pp. 493-522.

${ }^{10}$ Lynda Thompson, Michael Thompson and Andrea Reid, "Neurofeedback Outcomes in Clients with Asperger's Syndrome," Applied Psychophysiology and Biofeedback 35, No. 1 (2010), pp. 63-81. 
academic performance. In different studies, the approaches used in implementing the NFT for autistics are slightly different from each other (Refer to Table 1). Most of the previous researches had opted for visual or audio, or both feedbacks together with rewards system in implementing the NFT. As previous studies had proved that most autistics have no difficulties when task given involving visual orienting, it can be inferred that main approach to be used in studies of NFT is visual feedback. However, the adoption of auditory feedback in neurofeedback system is not less popular as it is certainly meaningful element to assist sustaining attention performance $^{11}$ There had also research that employed additional approaches such as the motor or verbal response or both in the NFT. A notable aspect to be concerned when implementing this kind of feedbacks is the requirement of particular participants' involvement in a study. The researchers should first specify a convenience sample to be used. The higher functioning autistics are seen the right sample to participate in this kind of intensive as most of them have slight difficulties in motor skills (using fingers and hand coordination) and communication (using words correctly). Other NFT approach those most of the research teams adopted in their inventions was the rewards system. Rewards are a must to encourage and motivate the autistics for a better tasks completion. Indirectly, rewards system may provide positive reinforcement to the autistics' attention span. Therefore, most of the researchers had incorporated in their NFT intervention the games concept. The games concept was chosen as it is constant and immediate in providing rewards for every achievement those participants gain.

The holy Quran is a main guidance for Muslim's life. For Muslims, the Quran exposure among children with autism by listening to the Quran recitation and learning to recite the Quran is very crucial to ensure they stay calm and let them familiar with verses of the Quran ${ }^{12}$. Furthermore, listening to the Quran

11 Brendan Z. Allison et al., eds. Towards Practical Brain-Computer Interfaces (New York: Springer Science \& Business Media, 2012).

12 Siti Patonah Mohd Zulkifli Mohd Yusuf and Durriyyah Sharifah Hasan Adli, "Sound Therapy through Quranic Recitation in Dealing with Emotional and 
recitation as well as memorizing the verses can be one of therapy to the emotion, which is thus suitable to be practiced by HFAs who occasionally show some behavioural problems.

The hard situation when it comes to learn the Quran, the HFAs facing difficulties to sustain attention during learning. The use of traditional style of learning the Quran which requires the teachers to read verses of the Quran directly from the sacred text in front of the students may affects the HFAs' attention ${ }^{13}$. As different HFA students may use different learning style ${ }^{14}$, it should be the best way to provide them with multiple approaches of teaching, thus they would have the benefits from the learning moments. There are also apps or tools developed to facilitate memorization in learning among the autistics. However, previous studies showed that lack of the Quran tools or apps for the purpose of memorization were developed specifically for the Muslim autistics. If the apps or tools available, it might not be published and are only used for a small group. Therefore, there should be technological teaching aids specifically developed to suit the use for them ${ }^{15}$ specifically in memorizing the Quran verses.

In other issues, adopting the traditional method in memorizing the Quran verses requires students to only listen and follow the teachers' recitation repeatedly which will affect their mood or emotion. They might feel boring after learning for few minutes. However, by adapting several NFT approaches in an invention will be expected to enhance the HFAs' attention in memorizing the Quran verses. Therefore, the objective of this study is to measure and compare the effectiveness of two versions

Verbal Motor Skills Problems of Children with Autism," QURANICA International Journal of Quranic Research 5, No. 2 (2013), pp. 53-72.

13 Bilikis Banire, Nazean Jomhari and Rodina Ahmad "Visual Hybrid Development Learning System (VHDLS) Framework for Children with Autism," Journal of Autism and Developmental Disorders 45, No. 10 (2015), pp. 3069-3084.

14 Katherine D. Tsatsanis, "Heterogeneity in Learning Style in Asperger Syndrome and High-Functioning Autism," Topics in Language Disorders 24, No. 4 (2004), pp. 260-270.

15 Bertram O Ploog et al., "Use of Computer-Assisted Technologies (CAT) to Enhance Social, Communicative, and Language Development in Children with Autism Spectrum Disorders," Journal of Autism and Developmental Disorders 43, No. 2 (2013), pp. 301-322. 
of an invention using the neurofeedback training on the attention performance of HFA during memorization of the Quran verses.

This paper discusses the experimental study of version 1 and 2 of the Quran Memorization Tool (QMT) learning system using the neurofeedback training in enhancing the attention performance of HFAs through suitable neurofeedback training approaches. Other sections of this paper describe the methodology of the study, design of the QMT, present the findings, and provide the summary and conclusion of the study.

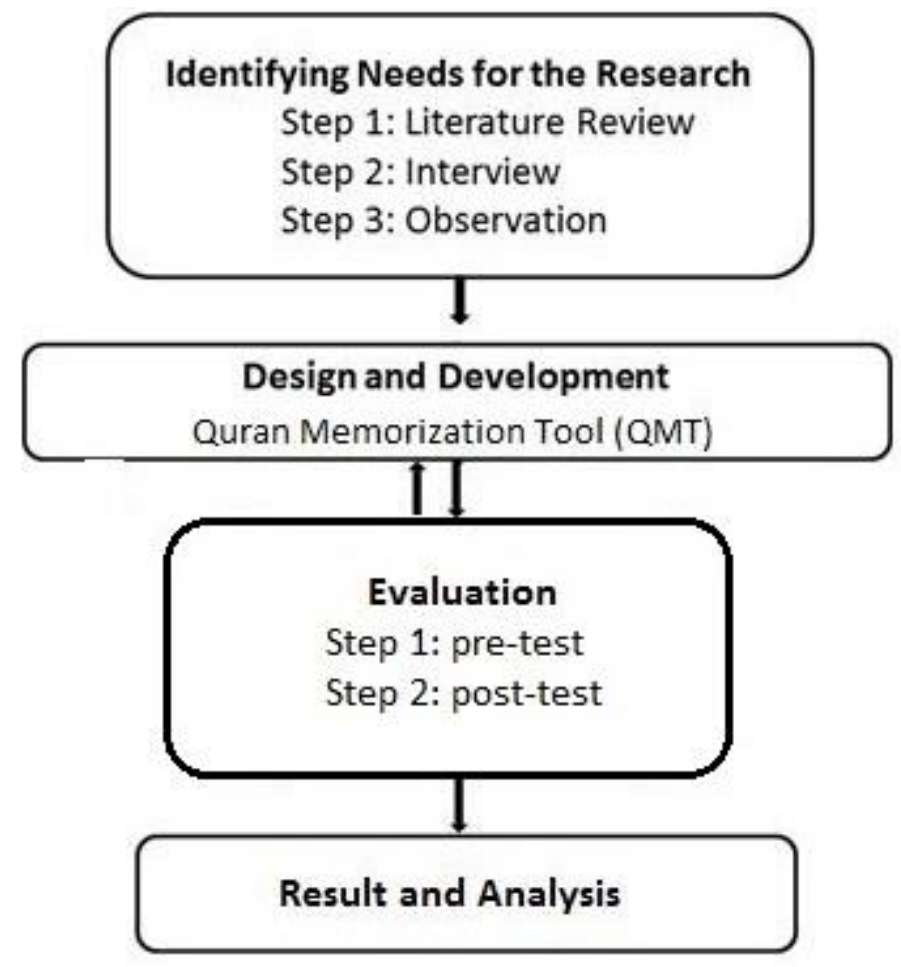

Figure 1. Research Methodology Flow

\section{Method}

This study adopted the mixed method research which involves the qualitative and quantitative methods. Qualitative and quantitative (mixed method) were used in the first phase of this research to identify the user requirements regarding the development of the proposed system which can assist the HFA students to enhance 
their attention performance during the Quran memorization. Quantitative method then was practiced to evaluate the students' memorization performance during the pre-test and post-test when using the developed system. NeuroSky MindWave headset (Mindset) was used as measurement tool to record the students' attention level.

\section{Identifying Needs for the Research}

In order to identify the user requirements, few steps have been taken through the literature review, interview, and observation. All the steps taken concerning a few elements:

1. The HFAs' attention performance.

2. The approaches employed in the NFT and the design of the appropriate framework to be adapted in the QMT those accommodate the criteria of the HFAs to prolong the attention span during memorization of the Quran verses.

3. The suitable measurement tool to be used in the system to capture the HFAs' level of attention during the memorization.

4. The identification of suitable Quran memorization techniques to be adopted in the system as HFA requires for slightly different technique compared to typical students.

5. The students' interest in leisure-time activities especially when the attention is distracted during learning.

\section{Outcomes: Approaches Used in Neurofeedback Training}

In previous studies, the approaches used in implementing the NFT for autistics are slightly different from each other. Some of the researchers did NFT assessment through visual or auditory feedbacks approaches, or other approaches such as verbal and motor response to assist the autistics train the brain functions to function better ${ }^{16}$ with various of rewards system introduced. Several documentations of previous studies those related to the approaches used in NFT to enhance the autistics' attention performance were reviewed as in Table 1.

${ }^{16}$ Navjot Saini and Ravinder Agarwal, "Neurofeedback as an Intervention for Brain Abilities Enhancement," International Journal of Advanced Research in Computer Engineering \& Technology 4, No. 5 (2015), pp. 1884-1886. 
Table 1. Approaches Used in NFT

\begin{tabular}{|c|c|c|c|}
\hline $\begin{array}{l}\text { Research } \\
\text { Objective }\end{array}$ & \multicolumn{2}{|c|}{ NFT approach(s) } & $\begin{array}{l}\text { Summary of } \\
\text { Findings }\end{array}$ \\
\hline $\begin{array}{l}\text { To improve } \\
\text { brain abilities } \\
\text { in the } \\
\text { individuals' } \\
\text { having brain } \\
\text { issue }^{17} \text {. }\end{array}$ & $\begin{array}{l}\text { Rewards are } \\
\text { received when } \\
\text { subject } \\
\text { successfully } \\
\text { self-direct the } \\
\text { brain waves to } \\
\text { accomplish } \\
\text { good } \\
\text { performance in } \\
\text { the game. }\end{array}$ & $\begin{array}{l}\text { Video game } \\
\text { with audio or } \\
\text { visual or } \\
\text { combined } \\
\text { audio-visual } \\
\text { feedback } \\
\text { Rewards }\end{array}$ & $\begin{array}{l}\text { After series } \\
\text { practice over } \\
\text { various } \\
\text { Neurofeedback } \\
\text { sessions, } \\
\text { sought brain } \\
\text { abilities can be } \\
\text { upgraded. }\end{array}$ \\
\hline $\begin{array}{l}\text { To assess the } \\
\text { viability of 19- } \\
\text { channel z- } \\
\text { score } \\
\text { Neurofeedback } \\
\text { (19ZNF) in a } \\
\text { clinical setting } \\
\text { among } \\
\text { attention- } \\
\text { deficit } \\
\text { hyperactivity } \\
\text { disorder } \\
(\text { ADHD) }\end{array}$ & $\begin{array}{l}\text { Fed back to the } \\
\text { patient with } \\
\text { simple non- } \\
\text { movie } \\
\text { animations } \\
\text { together with } \\
\text { discrete } \\
\text { auditory } \\
\text { reward tones } \\
\text { (Operant } \\
\text { conditioning } \\
\text { and the } \\
\text { attention task } \\
\text { working } \\
\text { simultaneously } \\
\text { ) }\end{array}$ & $\begin{array}{l}\text { Brainmaster } \\
\text { Flashgame } \\
\text { visual } \\
\text { feedback } \\
\text { Rewards }\end{array}$ & $\begin{array}{l}19 \mathrm{ZNF} \\
\text { enhanced } \\
\text { attention. }\end{array}$ \\
\hline
\end{tabular}

17 Navjot Saini and Ravinder Agarwal, "Neurofeedback as an Intervention for Brain Abilities Enhancement," pp. 1884-1886.

18 Nancy L. Wigton and Genomary Krigbaum, “Attention, Executive Function, Behavior, and Electrocortical Function, Significantly Improved with 19Channel Z-Score Neurofeedback in a Clinical Setting: A Pilot Study," Journal of Attention Disorders (2015), pp. 2. 


\begin{tabular}{|c|c|c|c|}
\hline $\begin{array}{l}\text { Research } \\
\text { Objective }\end{array}$ & \multicolumn{2}{|c|}{ NFT approach(s) } & $\begin{array}{l}\text { Summary of } \\
\text { Findings }\end{array}$ \\
\hline $\begin{array}{l}\text { To assess the } \\
\text { adequacy of } 2 \\
\text { PC attention } \\
\text { training } \\
\text { systems } \\
\text { regulated in } \\
\text { school for } \\
\text { youngsters } \\
\text { with ADHD } \\
\text { 19. }\end{array}$ & $\begin{array}{l}\text { A dolphin } \\
\text { character } \\
\text { swims down to } \\
\text { the base of the } \\
\text { sea to gather } \\
\text { coins from a } \\
\text { treasure chest, } \\
\text { and the child } \\
\text { gains points. In } \\
\text { the event that } \\
\text { the child is } \\
\text { distracted, the } \\
\text { dolphin swims } \\
\text { back up to the } \\
\text { surface of the } \\
\text { sea. }\end{array}$ & $\begin{array}{l}\text { Video game } \\
\text { (Moving } \\
\text { character) with } \\
\text { audio and } \\
\text { visual } \\
\text { feedback } \\
\text { Rewards }\end{array}$ & $\begin{array}{l}\text { Enhancements } \\
\text { in attention } \\
\text { and executive } \\
\text { control, } \\
\text { demonstrating } \\
\text { that this } \\
\text { intercession } \\
\text { holds } \\
\text { guarantee as } \\
\text { an alternative } \\
\text { treatment for } \\
\text { youngsters } \\
\text { with ADHD. }\end{array}$ \\
\hline $\begin{array}{l}\text { To ensure an } \\
\text { appealing play } \\
\text { experience that } \\
\text { will retain a } \\
\text { subject's } \\
\text { interest }^{20} \text {. }\end{array}$ & $\begin{array}{l}\text { Graphical } \\
\text { overlay is } \\
\text { presented on } \\
\text { top of a } \\
\text { running game } \\
\text { that clouds the } \\
\text { fundamental } \\
\text { game when the } \\
\text { subject is not } \\
\text { in the craved } \\
\text { physiological } \\
\text { state. }\end{array}$ & $\begin{array}{l}\text { Biofeedback } \\
\text { games with } \\
\text { visual } \\
\text { feedback } \\
\text { (altering } \\
\text { display } \\
\text { graphics) }\end{array}$ & $\begin{array}{l}\text { Ready to draw } \\
\text { in the subject's } \\
\text { enthusiasm } \\
\text { more than a } \\
\text { long haul } \\
\text { while playing } \\
\text { the game. }\end{array}$ \\
\hline
\end{tabular}

19 Naomi J. Steiner, "Neurofeedback and Cognitive Attention Training for Children with Attention-Deficit Hyperactivity Disorder in Schools," Journal of Developmental \& Behavioral Pediatrics 35, 2014, pp. 18-27.

20 Regal L. Mandryk et al. "Games as Neurofeedback Training for Children with FASD". In: Proceedings of the 12th International Conference on Interaction Design and Children - IDC '13.; 2013, pp. 165-172. 


\begin{tabular}{|c|c|c|c|}
\hline $\begin{array}{l}\text { Research } \\
\text { Objective }\end{array}$ & \multicolumn{2}{|c|}{ NFT approach(s) } & $\begin{array}{l}\text { Summary of } \\
\text { Findings }\end{array}$ \\
\hline $\begin{array}{l}\text { 1) To examine } \\
\text { impacts of } \\
\text { NFT in a } \\
\text { neurofeedback } \\
\text { group. } \\
\text { 2) To explore } \\
\text { contrasts in } \\
\text { effects on } \\
\text { attention tasks } \\
\text { with the } \\
\text { brainwave } \\
\text { activity } \\
\text { produced }^{21} \text {. }\end{array}$ & $\begin{array}{l}\text { Subjects are } \\
\text { required to } \\
\text { select any one } \\
\text { game, } \\
\text { Painting, or } \\
\text { Making a cup, } \\
\text { or Bending a } \\
\text { spoon, or } \\
\text { shooting an } \\
\text { arrow. When } \\
\text { the game } \\
\text { successfully } \\
\text { completed, } \\
\text { another bonus } \\
\text { game would be } \\
\text { offered as a } \\
\text { reward. }\end{array}$ & $\begin{array}{l}\text { Game with } \\
\text { audio (beeps) } \\
\text { or visual } \\
\text { (colour } \\
\text { changes) } \\
\text { feedback only } \\
\text { if the game } \\
\text { successfully } \\
\text { completed } \\
\text { Game with } \\
\text { motor response } \\
\text { Rewards }\end{array}$ & $\begin{array}{l}\text { The NFT } \\
\text { group showed } \\
\text { significantly } \\
\text { improved } \\
\text { scores on the } \\
\text { all tests } \\
\text { (CCTT-2, } \\
\text { SCWT, and } \\
\text { Digit Span } \\
\text { tasks). }\end{array}$ \\
\hline $\begin{array}{l}\text { To explore the } \\
\text { hypothesis: } \\
\text { NFT decreases } \\
\text { theta activity } \\
\text { while } \\
\text { remunerating } \\
\text { low beta } \\
\text { activity, as per } \\
\text { the standard } \\
\text { ADHD } \\
\text { treatment } \\
\text { protocol }{ }^{22} \text { [21]. }\end{array}$ & $\begin{array}{l}\text { Visual } \\
\text { selective } \\
\text { attention: } \\
\text { Subject needs } \\
\text { to react to one } \\
\text { specific } \\
\text { character on } \\
\text { the PC screen } \\
\text { while } \\
\text { disregarding } \\
\text { different } \\
\text { characters } \\
\text { amid } 5 \text { min. }\end{array}$ & $\begin{array}{l}\text { Activity with } \\
\text { visual and } \\
\text { audio feedback } \\
\text { Activity with } \\
\text { verbal and } \\
\text { motor response }\end{array}$ & $\begin{array}{l}\text { Noteworthy } \\
\text { change in } \\
\text { attentional } \\
\text { control, } \\
\text { cognitive } \\
\text { flexibility and } \\
\text { goal setting } \\
\text { were noted for } \\
\text { the subjects. }\end{array}$ \\
\hline
\end{tabular}

${ }^{21}$ Changhee Hong and Inkyoung Lee, "Effects of Neurofeedback Training on Attention in Children with Intellectual Disability," Journal of Neurotherapy 16, No. 2 (2012), pp. 110-122.

22 Kouijzer MEJ, "Neurofeedback Improves Executive Functioning in Children with Autism Spectrum Disorders," Research in Autism Spectrum Disorders 3, No. 1 (2009), pp. 145-162. 


\begin{tabular}{|c|c|c|c|}
\hline \multirow[t]{2}{*}{$\begin{array}{l}\text { Research } \\
\text { Objective }\end{array}$} & \multicolumn{2}{|l|}{ NFT approach(s) } & $\begin{array}{c}\text { Summary } \\
\text { of Findings }\end{array}$ \\
\hline & $\begin{array}{l}\text { (measured by the Continuous } \\
\text { Performance Test (CPT)). } \\
\text { Auditory selective attention: } \\
\text { Subjects need to react to sets } \\
\text { of } 3 \text { beeps while disregarding } \\
\text { arrangements of } 2 \text { or } 4 \text { beeps. } \\
\text { (Measured by the Test of } \\
\text { Sustained Selected Attention } \\
\text { (TOSSA)). Verbal response } \\
\text { inhibition: Subjects need to } \\
\text { peruse out loud at the earliest } \\
\text { opportunity. (Assessed by the } \\
\text { Stroop test). Motor response } \\
\text { inhibition: Based on the } \\
\text { quantity of commission } \\
\text { errors. (Inhibition was } \\
\text { assessed with the response } \\
\text { inhibition score (RIS; range } \\
\text { 0-100) of the TOSSA). }\end{array}$ & & \\
\hline $\begin{array}{l}\text { To } \\
\text { research } \\
\text { impacts } \\
\text { of } \\
\text { motiva- } \\
\text { tion on } \\
\text { neural } \\
\text { correlates } \\
\text { of } \\
\text { response } \\
\text { conflict } \\
\text { and } \\
\text { attention } \\
\text { in } \\
\text { ADHD } 23\end{array}$ & $\begin{array}{l}\text { A go/no-go paradigm was } \\
\text { used. Subjects were required } \\
\text { to give attention to a central } \\
\text { point of stimuli within } 100 \\
\text { msec. When a frequent "go" } \\
\text { stimulus (green aliens) } \\
\text { popped up, subjects were } \\
\text { instructed to press the button, } \\
\text { or conversely to cease from } \\
\text { reacting to an infrequent "no- } \\
\text { go" stimulus (black aliens). } \\
\text { Subjects would pick up } 1 \\
\text { point for each convenient } \\
\text { reaction or lost } 1 \text { point for } \\
\text { each slow or missed reaction. }\end{array}$ & $\begin{array}{l}\text { Activity } \\
\text { with } \\
\text { visual } \\
\text { feedback } \\
\text { and motor } \\
\text { response } \\
\text { (quick } \\
\text { response } \\
\text { to the } \\
\text { right } \\
\text { answers) } \\
\text { Rewards }\end{array}$ & $\begin{array}{l}\text { The } \\
\text { motiva- } \\
\text { tional } \\
\text { incentives } \\
\text { were } \\
\text { viable in } \\
\text { improving } \\
\text { attention } \\
\text { in ADHD. }\end{array}$ \\
\hline
\end{tabular}

23 Madeleine J. Groom et al. "Effects of Motivation and Medication on Electrophysiological Markers of Response Inhibition in Children with 
In this study, the most preferred approaches to be adopted in the NFT intervention were visual feedback, audio feedback, verbal response, and rewards (acted as motivation). Although the HFAs have slight difficulties in motor skills, the use of computer mouse was expected would give harder situation for them because some of them have difficulty to differentiate between a left and right mouse click while at the same time they are required to give attention to the activity on the screen ${ }^{24}$. So that, this study would not focus to adopt the motor response approach.

\section{Components of the System Framework}

This study adapted the components from previous studies which suggested different frameworks as a design of NFT system. Each of the QMT components is explained in Table 2.

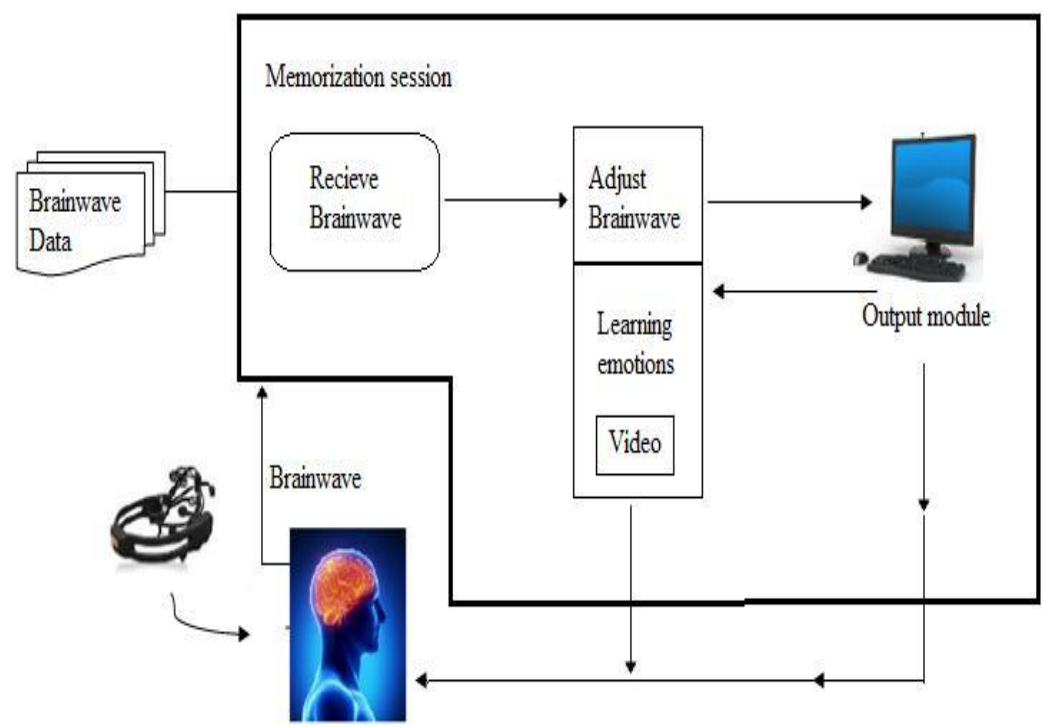

Figure 1. Quran Memorization Tool Framework

Attention-Deficit/Hyperactivity Disorder," Biological Psychiatry 67, No. 7 (2010), pp. 624-631.

24 AbilityNet. Autism and Computing for Children Under: How can a computer help. Website abilitynet.org.uk. accessed on August 23, 2016. https://www.abilitynet.org.uk/play/documents/AutismandComputingfactsheet v4Play.pdf. Published 2010. 
The components of the QMT system framework are based on the highlighted approaches (visual feedback, audio feedback, verbal response, and rewards).

Table 1. Summary of Description of QMT Framework

\begin{tabular}{|c|l|l|}
\hline No. & $\begin{array}{l}\text { Component of } \\
\text { framework }\end{array}$ & \multicolumn{1}{|c|}{ Description of component } \\
\hline 1 & $\begin{array}{l}\text { Memorization } \\
\text { session }\end{array}$ & $\begin{array}{l}\text { The HFA views the Quran sacred texts on } \\
\text { the computer screen and listening to the } \\
\text { recitation produced by the Quranic audio. } \\
\text { HFA is also required to imitate the } \\
\text { recitation either together with the played } \\
\text { Quranic audio or right after the audio } \\
\text { finishes its recitation. }\end{array}$ \\
\hline 2 & $\begin{array}{l}\text { Receive } \\
\text { brainwave }\end{array}$ & $\begin{array}{l}\text { The HFA's brain wave (EEG signal) is } \\
\text { measured for the preliminary processing } \\
\text { before the attention score is computed. }\end{array}$ \\
\hline 3 & $\begin{array}{l}\text { Brainwave } \\
\text { data }\end{array}$ & $\begin{array}{l}\text { Store the entire recorded EEG signal of } \\
\text { HFA's brain activity during memorization } \\
\text { session. }\end{array}$ \\
\hline 5 & $\begin{array}{l}\text { Abstract animation videos, one with and } \\
\text { without subtitles are used for the purpose } \\
\text { of handling the HFA's emotion to perform } \\
\text { an effective learning during Quran } \\
\text { emotions }\end{array}$ \\
\hline memorization.
\end{tabular}

${ }^{25}$ Yun-Sick Sung, Kyung-Eun Cho and Ky-Hyun Um, "A Framework for Electroencephalogram Process at Real-Time using Brainwave," Journal of Korea Multimedia Society 14, No. 9 (2011), pp. 1202-1209.

${ }^{26}$ Yue Chen Kuo and Tsu Yang Wang, "An English Listening Learning Framework Based on the Learning Emotion" (International Conference on ELearning, E-Business, Enterprise Information Systems, \& E-Government, 2013), pp. 287-288.

27 Yun-Sick Sung, Kyung-Eun Choa and Ky-Hyun Um, "A Framework for Electroencephalogram Process at Real-Time using Brainwave," pp. 12021209. 


\begin{tabular}{|l|l|l|}
\hline & $\begin{array}{l}\text { module (memorizing the Quran verses) } \\
\text { after they are in a concentrate mode } \\
\text { (attention scores greater than 40). }\end{array}$ \\
\hline 6 & $\begin{array}{l}\text { As the type of videos (stimuli) presented } \\
\text { may affects the ability to sustain attention, } \\
\text { the abstract animation video (multiple } \\
\text { Video } \\
\text { (Selective } \\
\text { attention, } \\
\text { Sustain } \\
\text { attention, } \\
\text { Memorization } \\
\left.\text { skill }{ }^{28}\right)\end{array}$ & $\begin{array}{l}\text { the HFA to give attention to that particular } \\
\text { video (familiar stimulus those have been } \\
\text { stored in their working memory as some } \\
\text { autistics experience learning in a sensory } \\
\text { room surrounded with animation of } \\
\text { multiple colours). }\end{array}$ \\
\hline 7 & $\begin{array}{l}\text { When the attention score detected is } 40 \text { or } \\
\text { below, the videos will be displayed to the } \\
\text { HFA. } \\
\text { The videos as motivation to the learners. } \\
\text { Output module } \\
\text { (self- } \\
\text { rewarding })^{29}\end{array}$ & $\begin{array}{l}\text { other words, motivation is one of the } \\
\text { purposes of reward system. } \\
\text { When the HFA's attention greater than 40, } \\
\text { the system goes back to the learning } \\
\text { module (memorizing the Quran verses). }\end{array}$ \\
\hline
\end{tabular}

\section{NeuroSky EEG Biosensor Technology}

For the purpose of this research project, the NeuroSky MindWave Mobile was used as it is a type of mobile compatible device and it could measure the attention level of the users. The characteristic features resemble other brainwave reading headsets ${ }^{30}$. Basically,

28 Thomas KP, Vinod AP and Guan C. "Design of an Online EEG Based Neurofeedback Game for Enhancing Attention and Memory" (Annual International Conference of the IEEE Engineering in Medicine and Biology Society 2013), pp. 433-436.

${ }^{29}$ Luca Szegletes and Bertalan Forstner, "An Introduction to a Neurofeedback based Self - Rewarding Framework on Mobile Devices using Modern HCIs," International Journal of Information and Education Technology 1, No. 7 (2013), pp. 27-34.

30 "Brainwave Sensing Headset", Website NeuroSky, http://store.neurosky.com/pages/mindwave. 
this type of headset gives outputs of NeuroSky eSense meters which display the attention and meditation level ranges from 0 to 100. The attention values are used to record the participants' level of effort. The higher the participant's effort level, the nearer the attention score to 100 but if they make no effort at all, the attention score nearer $0^{31}$.

\section{Quran Memorization Technique}

In order to identify the most suitable technique in the Quran memorization for HFAs, the literature review of the existing Quran memorization techniques and observation on the HFA students during the Quran memorization sessions had contributed to the ideas of the functions to be performed in the QMT. The development of the QMT then will include the listening, and reciting time (verbal response) by adapting the function:

1. Listening to the continuous recitation of a sura without silent duration between two verses.

2. Fixed silent duration between two verses after the Quranic audio recitation for every verse to allow the student follows the recitation.

3. Adjustable silent duration between two verses after the Quranic audio recitation for every verse to allow the student follows the recitation.

4. Adjustable number of repetition of a recitation verse.

\section{Students' Interest in Leisure-time Activities}

Students with high-functioning autism are easily to lose focus when learning. When the HFAs' attention was distracted, they tend to do other things they like. During the inattention in the middle of learning session, they were seen interested to watch videos, work with hand drawings, singing, playing video games, and reading comics. Based on the results of observation and interview conducted, this research would focus on providing videos in the development of the QMT as its visual and audio feedback as well as reward (motivation) to elevate the students' attention level.

${ }^{31}$ Katie Crowley and James McDermott, "Mapping Brain Signals To Music Via Executable Graphs," Creat Commons Attrib 30 Unported. 2015. 


\section{Design and Development of the QMT}

According to the outcomes from preliminary study, the ideas about the design of QMT are constructed which is divided into two stages, QMT version 1 (before pre-test) and QMT version 2 (after pre-test). Few characteristics are considered to design the GUI of the system. The GUI should be simple, useful, helpful, and joyful for the users (teacher and students). The selection of colours of the system interface is very important as people with autism easily distracted with multicolours. The following figures show the interface of the QMT.

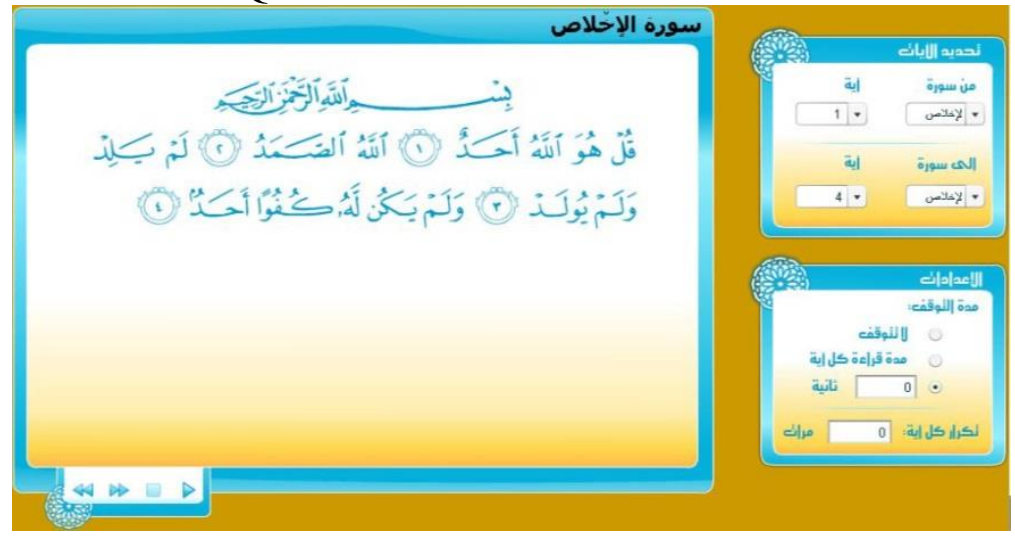

Figure 3. The system interface consists of three main components; i) specification of the surah and verse number, ii) settings of the recitation mode, and iii) Quran sacred text area

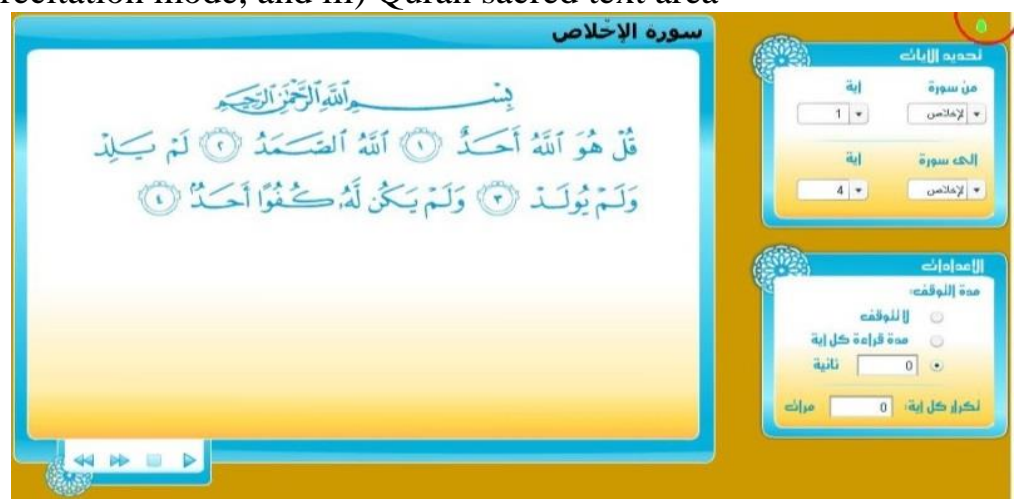

Figure 4. When the Mindset is put on the student's scalp detects the brainwaves (attention value), a small green light on the top of the system displays on the web page. 


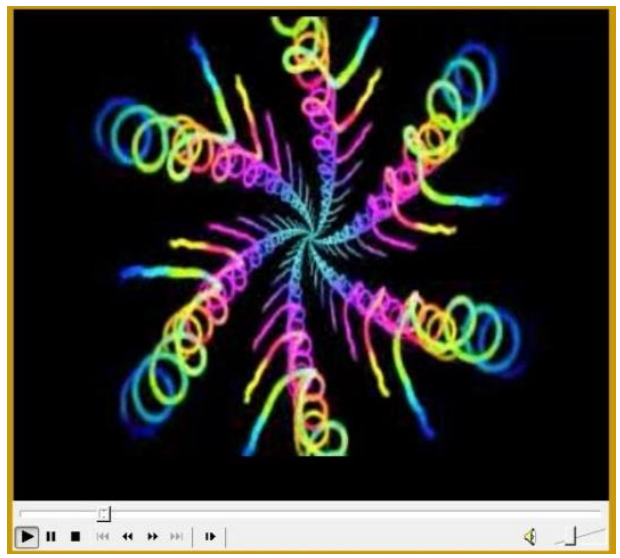

Figure 2. Video with Abstract Animation

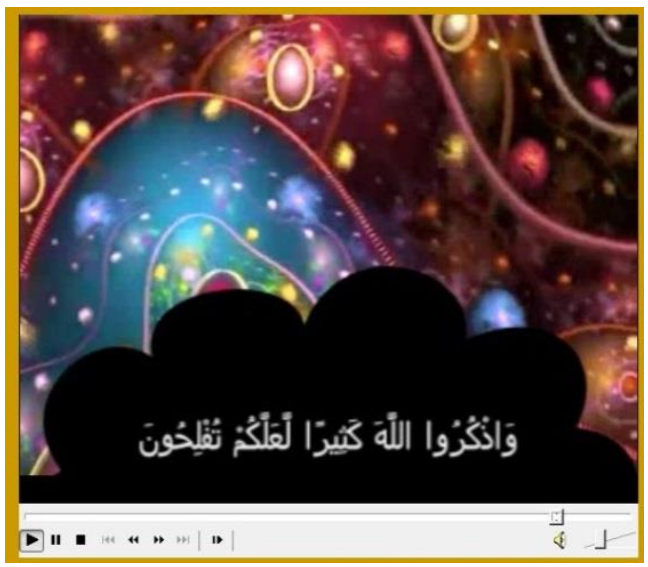

Figure 6. Video with Abstract Animation and Subtitles

The Figure 5 and Figure 6 illustrate the videos provided by the system when the student's attention scores below the standard. Both videos reciting the sura al-Jumu'ah but the video as illustrated in the Fig. 6 have its subtitle as additional visual feedback. The element of video is included only in the QMT version 2 design. The QMT version 1 design of the system only displays the interfaces as illustrated in the Fig. 3 and Fig. 4. The differentiation between the designs is to measure the effectiveness of the Quran Memorization Tool on the attention performance of the HFAs. 


\section{Evaluation of QMT}

The evaluation objectives are to measure and compare the effectiveness between the QMT version 1 and 2 as the intervention that enhance the attention performance of the HFAs during memorization of the Quran verses. The result of the pre-test (using QMT version 1) then would be compared to the result of the posttest (using QMT version 2) to determine either the enhanced QMT could improve the HFAs' attention performance or vice versa.

The independent variables involved were approaches used in the QMT; visual feedback, audio feedback, and reward. The approaches were selected based on the reviews done on previous studies concerning the approaches used in NFT to enhance the autistics' attention performance.

The dependent variables involved were the HFAs' attention state; poor attention, normal attention, or high attention. According to the NeuroSky eSense meters which are explained earlier, the three categorizations are based on the percentage of time the participant's levels of attention scores below $40^{32}$ [30]. The HFAs' attention states were grouped into three categories as described in the Table 3 and it is crucial as indicator of effectiveness of the two versions of the QMT.

Table 2: Participant's Categorization

\begin{tabular}{|c|c|}
\hline If $(X>=25)$ & Poor Attention \\
\hline If $(10<X<25)$ & Normal Attention \\
\hline If $(X<=10)$ & High Attention \\
\hline$X=\sum$ Attention time below 40 / overall time * 100
\end{tabular}

During the experimental evaluation, there are two experimental controls involved. The first is the same HFA students participated in both pre-test and post-test. The second is verbal response approach which was used in both first and second development of the QMT.

${ }^{32}$ Katie Crowley et al., "Evaluating a Brain-Computer Interface to Categorise Human Emotional Response" (Proceedings - 10th IEEE International Conference on Advanced Learning Technologies, ICALT 2010, 2010), pp. 276-278. 


\section{Experiment Methods and Procedures}

Participants - Ten students with high-functioning autism were selected for the experimental evaluation of the QMT. The students comprised of 9 boys and 1 girl. These students attend for daily or weekend Quran class at one of the Islamic center for children with special needs in Petaling Jaya; Akademi Fakih Intelek. They are 8 to 29 years of age.

Experiment Settings - The evaluation sessions were conducted in an office at Akademi Fakih Intelek with one table and one chair provided. A computer was put on the table those facing the chair. A convenient place should be used to ensure the environment is good and apart from other distraction during the evaluation.

Evaluation Procedures - The participants were observed during the pre-test (QMT version 1: without visual, audio feedback, and rewards) and post-test (QMT version 2: with visual, audio feedback, and rewards). The evaluation procedures used in both tests were the same. The procedures are listed as follows:

1. The evaluation of the system is conducted in an office in the morning.

2. Participants are reciting Ruqyah (behavioral therapy using Quran) first before the evaluation.

3. When students come into the office, they sit down and take some relaxation time in a comfortable condition for 2 to 3 minutes.

4. Participants are given instructions for the evaluation.

5. Then, attach the Mindset on the head and start the evaluation.

6. The student listens to the sura al-Jumu'ah which consists of 11 verses.

7. The researcher sits in the office, controls the evaluation and keep notes.

\section{Result and Discussion}

Pre-test - Based on the participant's categorization described in the Table 3, the HFA students' attention scores during the memorization of Quran verses using the QMT version 1 could be categorized. The total students those have High Attention during the memorization is 3 students, Normal Attention is 1 student while the total for Poor Attention is 6 students. 


\section{Post-test}

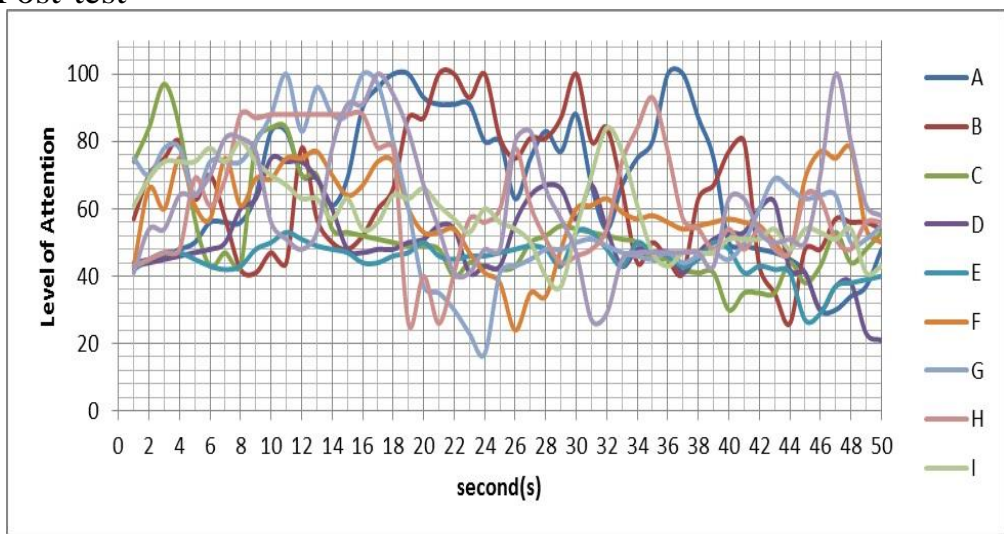

Figure 3. Students' Attention Performance within 50 Seconds

In between the 18th second to 33rd second and 39th second to 50th second, the graph in the Fig. 7 shows that most of the students' attention level getting decreased and elevated back for a few seconds. At these points, the students were likely watching the video with abstract animation provided when their level of attention scored 40 and below. After the attention elevated and scored above 40, the abstract animation video disappeared and they continued the memorization session back.

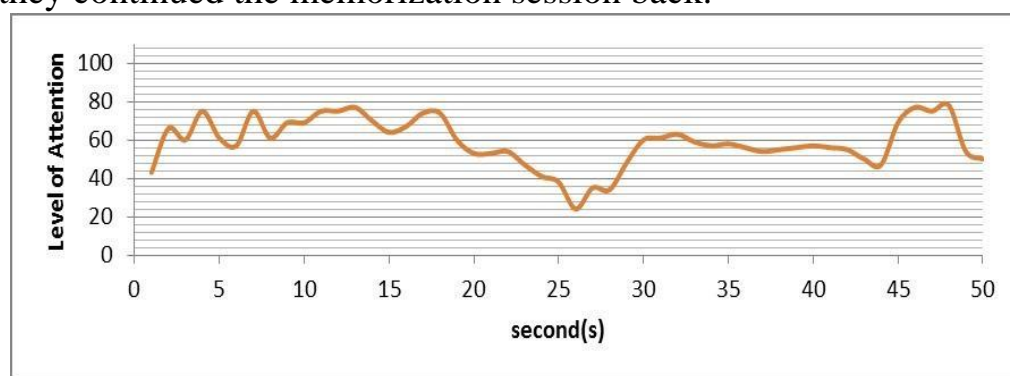

Figure 4. One of the student's attention levels

The Fig. 8 shows one of the students' attention levels during the memorization of Quran verses using the QMT version 2. It can be observed that at the $25^{\text {th }}$ second, the attention level getting decreased. At this point, the student was provided with the video with abstract animation. As a result of the feedback given by the student, the attention level elevated back during the $29^{\text {th }}$ second.

According to the participant's categorization described in the Table 3, the HFA students' attention scores during the 
memorization of Quran verses using the QMT version 2 could be categorized. The total students those have High Attention during the memorization is 8 students while the total for Normal Attention is 2 students. There are no students categorized in Poor Attention.

In comparison to the result in the pre-test, the ratio of students those categorized in High Attention during the post-test are increased from 3:10 to 4:5 when using the QMT version 2 which resulted in more effective in improving the HFAs' attention performance. The results obtained in this experimental evaluation were also analyzed using the Wilcoxon Signed Ranks test to show strong evidence in the analysis.

The Table 4 shows that all 10 students those participated in the experimental evaluation performed well during the post-test with the total of students categorized by High Attention was higher compared to the pre-test.

Table 3. Wilcoxon Signed Ranks Test

\begin{tabular}{|c|c|c|c|c|}
\hline \multicolumn{2}{|c|}{} & $\mathrm{N}$ & $\begin{array}{c}\text { Mean } \\
\text { Rank }\end{array}$ & $\begin{array}{c}\text { Sum of } \\
\text { Ranks }\end{array}$ \\
\hline \multirow{2}{*}{$\begin{array}{c}\text { X value during } \\
\text { Post-test - X value } \\
\text { during Pre-test }\end{array}$} & Negative Ranks & $10^{\mathrm{a}}$ & 5.50 & 55.00 \\
\cline { 2 - 5 } & Positive Ranks & $0^{\mathrm{b}}$ & .00 & .00 \\
\cline { 2 - 5 } & Ties & $0^{\mathrm{c}}$ & & \\
\cline { 2 - 5 } & Total & 10 & & \\
\hline
\end{tabular}

Based on the Table 5, it shows that the $p$-value is 0.005 which is less than 0.05 . It can be concluded that there was significant difference of the HFA student's attention level between the pretest and the post-test. It was also proved that the QMT version 2 is effective in improving the HFAs' attention performance.

\begin{tabular}{|c|c|}
\multicolumn{1}{|c}{ Table 4. Test Statistics } \\
\hline & $\begin{array}{c}\text { X value during Post-test } \\
-\mathrm{X} \text { value during Pre-test }\end{array}$ \\
\hline $\mathrm{Z}$ & $-2.805^{\mathrm{b}}$ \\
\hline Asymp. Sig. (2-tailed) & 0.005 \\
\hline
\end{tabular}

\section{Conclusions}

Based on the analysis of the HFAs' attention performance during the pre-test and the post-test, it is believed that the HFAs' attention performance was enhanced when the QMT adapting the approaches visual and audio feedback, verbal response, and 
rewards. Through the visual feedback and rewards approaches of neurofeedback training, they were rewarded to watch a video with abstract animation in the middle of distracted concentration mode (attention level scores 40 or below) during the use of the QMT as a memorization tool. The abstract animation video was presented with multiple colours representation style as some autistics experience learning in a sensory room surrounded with animation of multiple colours. This is important to ensure the selective attention encourages the HFA to give attention to the particular video (familiar stimulus those have been stored in their working memory). Although the HFAs have difficulties in audio processing, this study tried to put an effort to deal with the weakness by adapting the audio feedback approach in the QMT. The video displayed during the distracted concentration mode was embedded with the sura al-Jumu'ah recitation. The Quran recitation was more preferred as the audio feedback even though it acted as refreshment because this study aimed the HFA students to get some refreshing while memorizing the Quran verses unconsciously. Thus, they get the benefits from the Quran memorization session. Based on the observation conducted during the user requirements identification, the HFAs are able to memorize the Quran verses effectively through listening and mimic the adults' voice. Aware of this situation, the verbal response approach of neurofeedback training was adapted in the QMT. As repeating read or recite something consciously, later it will come out from mouth according to one's senses or perception.

According to the findings of this study, it can be deduced that the HFAs are able to memorize the verses of Quran for a longer term as typical individuals by using a unique method. This study is also expected to contribute something valuable to the Muslim autistic community as they are also have the rights to learn, understand, and instill all teachings of the Quran in their heart.

\section{Acknowledgement}

The authors thank all the members of Yayasan Faqeh including the students, teachers, and management for their support in conducting this research study which is in collaboration with Centre Quranic Research, University of Malaya. 


\section{References}

Maimun Aqsha Lubis et al. "The Effectiveness of Strategies and Techniques in Teaching and Learning Islamic Education", WSEAS Transactions on Information Science and Applications 6, No. 8 (2009), pp. 218-224.

Wan Noor Hazlina Wan Jusoh and Kamaruzaman Jusoff. "Using Multimedia In Teaching Islamic Studies." Journal Media and Communication Studies 1, No. 5 (2009), pp. 86-94.

Siti Iradah Ismail and Rabiah Abdul Kadir. "EduTism: An Assistive Educational System for the Treatment of Autism Children." In Visual Informatics: Sustaining Research and Innovations, eds. Halimah Badioze Zaman et al. Selangor: Springer Berlin Heidelberg; 2011.

Porayska-Pomsta, K. et al. "Developing Technology for Autism: An Interdisciplinary Approach." Personal and Ubiquitous Computing 16, No. 2 (2012), pp. 117-127.

Hammond, D. Corydon. "What Is Neurofeedback?" Journal of Neurotheraphy 10, No. 4 (2007), pp. 25-36.

Choi, Wonjae, Lee, Seungwon and Park, Junhyuck. "EEGBiofeedback Intervention Improves Balance in Stroke Survivor," Indian Journal of Science \& Technology 8, No. 18 (2015), pp. 1.

Hammond, D. Corydon. "What Is Neurofeedback?: An Update," Journal of Neurotheraphy 15, No. 4 (2011), pp. 305-336.

Lubar, Joel F. Neurofeedback for the Management of AttentionDeficit/Hyperactivity Disorders. In Biofeedback: A Practitioner's Guide, eds. Mark S Schwartz. 2nd ed, New York: Guilford Press; 1995.

Thompson, Lynda, Thompson, Michael and Reid, Andrea. "Neurofeedback Outcomes in Clients with Asperger's Syndrome." Applied Psychophysiology and Biofeedback 35, No. 1 (2010), pp. 63-81.

Allison, Brendan Z. et al., eds. Towards Practical Brain-Computer Interfaces (New York: Springer Science \& Business Media, 2012).

Siti Patonah Mohd Zulkifli Mohd Yusuf and Durriyyah Sharifah Hasan Adli. "Sound Therapy through Quranic Recitation in Dealing with Emotional and Verbal Motor Skills Problems of 
Children with Autism," QURANICA International Journal of Quranic Research 5, No. 2 (2013), pp. 53-72.

Bilikis Banire, Nazean Jomhari and Rodina Ahmad. "Visual Hybrid Development Learning System (VHDLS) Framework for Children with Autism," Journal of Autism and Developmental Disorders 45, No. 10 (2015), pp. 3069-3084.

Tsatsanis, Katherine D. "Heterogeneity in Learning Style in Asperger Syndrome and High-Functioning Autism." Topics in Language Disorders 24, No. 4 (2004), pp. 260-270.

Ploog, Bertram O. et al., "Use of Computer-Assisted Technologies (CAT) to Enhance Social, Communicative, and Language Development in Children with Autism Spectrum Disorders," Journal of Autism and Developmental Disorders 43, No. 2 (2013), pp. 301-322.

Saini, Navjot, and Agarwal, Ravinder. "Neurofeedback as an Intervention for Brain Abilities Enhancement." International Journal of Advanced Research in Computer Engineering \& Technology 4, No. 5 (2015), pp. 1884-1886.

Wigton, Nancy L. and Krigbaum, Genomary. "Attention, Executive Function, Behavior, and Electrocortical Function, Significantly Improved with 19-Channel Z-Score Neurofeedback in a Clinical Setting: A Pilot Study." Journal of Attention Disorders (2015), pp. 2.

Steiner, Naomi J. "Neurofeedback and Cognitive Attention Training for Children with Attention-Deficit Hyperactivity Disorder in Schools," Journal of Developmental \& Behavioral Pediatrics 35, 2014, pp. 18-27.

Mandryk, Regal L. et al. "Games as Neurofeedback Training for Children with FASD." Proceedings of the 12th International Conference on Interaction Design and Children - IDC '13.; 2013.

Hong, Changhee and Lee, Inkyoung. "Effects of Neurofeedback Training on Attention in Children with Intellectual Disability," Journal of Neurotherapy 16, No. 2 (2012), pp. 110-122.

MEJ, Kouijzer. "Neurofeedback Improves Executive Functioning in Children with Autism Spectrum Disorders." Research in Autism Spectrum Disorders 3, No. 1 (2009), pp. 145-162.

Groom, Madeleine J. et al. "Effects of Motivation and Medication on Electrophysiological Markers of Response Inhibition in 
Children with Attention-Deficit/Hyperactivity Disorder," Biological Psychiatry 67, No. 7 (2010), pp. 624-631.

AbilityNet. Autism and Computing for Children Under: How can a computer help. Website abilitynet.org.uk. accessed on August 23 , 2016. https://www.abilitynet.org.uk/play/documents/AutismandComp utingfactsheetv4Play.pdf. Published 2010.

Sung, Yun-Sick, Cho, Kyung-Eun and Um, Ky-Hyun "A Framework for Electroencephalogram Process at Real-Time using Brainwave," Journal of Korea Multimedia Society 14, No. 9 (2011), pp. 1202-1209.

Kuo, Yue Chen and Wang, Tsu Yang "An English Listening Learning Framework Based on the Learning Emotion". International Conference on E-Learning, E-Business, Enterprise Information Systems, \& E-Government, 2013.

KP, Thomas, AP, Vinod and C., Guan. "Design of an Online EEG Based Neurofeedback Game for Enhancing Attention and Memory." Annual International Conference of the IEEE Engineering in Medicine and Biology Society 2013.

Szegletes Luca, and Forstner, Bertalan. "An Introduction to a Neurofeedback - based Self - Rewarding Framework on Mobile Devices using Modern HCIs." International Journal of Information and Education Technology 1, No. 7 (2013), pp. 2734.

"Brainwave Sensing Headset". Website NeuroSky, http://store.neurosky.com/pages/mindwave.

Crowley Katie, and McDermott, James. "Mapping Brain Signals To Music Via Executable Graphs." Creat Commons Attrib 30 Unported. 2015.

Crowley, Katie et al., "Evaluating a Brain-Computer Interface to Categorise Human Emotional Response." Proceedings - 10th IEEE International Conference on Advanced Learning Technologies, ICALT 2010, 2010. 